\title{
STUDIES ON DEVELOPING RETINAL VESSELS* \\ VII. FLUORIDE-INDUCED VASO-OBLITERATION AND ITS \\ RELATION TO RETINAL MATURITY
}

\author{
BY \\ CHRISTOPHER PEDLER \\ Department of Pathology, Institute of Ophthalmology, University of London
}

SINCE it was first reported that oxygen had a specific vaso-obliterative action on the vessels of the immature retina (Ashton, Ward, and Serpell, 1953), a working hypothesis has been devised and certain experiments carried out in an attempt to understand the intermediate mechanism involved (Ashton, Graymore, and Pedler, 1957). In the latter paper it was suggested that the vessels might close through external pressure from fluid imbibition into the retina as a result of an interruption in glycolysis brought about by ambient hyperoxia. Experiments were also reported wherein vessel closure analogous to that following oxygen exposure could be induced by the intravitreal administration of established inhibitors of glycolysis, such as sodium fluoride, which was found to produce complete retinal vaso-obliteration in a consistently repeatable manner. This finding alone is not sufficient to support the idea of cell swelling as a cause of vaso-obliteration in the immature retina, and many other facets of this hypothesis still require experimental investigation; however, support has recently been provided by experiments (Graymore, 1958) which showed that, under defined conditions in vitro, excised retinae incubated in solutions containing known amounts of sodium fluoride underwent a significant increase in Wet Weight : Dry Weight ratio. Similarly, other experiments have demonstrated that the intravitreal injection of sodium fluoride into the intact living eye can result in a histologically measurable swelling of the inner cell layers of the immature but not of the mature retina (Pedler, 1959). Hence, if retinal swelling is responsible for the vaso-obliteration observed in the living eye, then the vessel closure should also show correlation with the degree of retinal maturity. This paper reports the results of some experiments designed first to investigate this possibility, and secondly to determine whether there is any similarity between the age at which fluoride ceases to affect the retinal vessels and that at which ambient hyperoxia becomes ineffective.

\section{Materials and Methods}

(1) Intravitreal Injection.-A previous paper on this subject (Ashton and others, 1957) gives details of the method used for intravitreal injection, but one small though important detail has been changed:

* Received for publication January 16, 1959. 
It is now considered essential for the tip of the needle to pass right through the vitreous to impinge upon the surface of the retina. If this is not done, it is common for some of the injected fluid to leak back along the needle track and to escape from the eye. When the retina is touched, this appears to rupture the vitreous surface so that flow takes place into the subhyaloid space.

(2) Direct Observation.-The results shown in the Table were all obtained by a method which allows both cinephotography and medium-power microscopic examination of the living retina using a stereoscopic optical technique. This method is fully described elsewhere (Ashton and Cook, 1954; Pedler, 1957) and no significant changes in it have been made.

TABLE

RELATIONSHIP BETWEEN AGE AND VASO-OBLITERATIVE ACTION OF INTRAVITREALLY INJECTED SODIUM FLUORIDE

\begin{tabular}{|c|c|c|c|c|c|c|}
\hline Exp. No. & $\begin{array}{l}\text { Age } \\
\text { (days) }\end{array}$ & $\begin{array}{l}\text { Weight } \\
\text { (g.) }\end{array}$ & $\begin{array}{l}\text { Dose } \\
\text { (ml.) }\end{array}$ & $\begin{array}{l}\text { Concentration } \\
\text { (per cent.) }\end{array}$ & $\begin{array}{l}\text { Degree of } \\
\text { Closure }\end{array}$ & $\begin{array}{l}\text { Time at which } \\
\text { Maximum Closure } \\
\text { was Seen (min.) }\end{array}$ \\
\hline 192 & 6 & 210 & $0 \cdot 2$ & 0.61 & ++ & 22 \\
\hline 194 & \multirow[t]{2}{*}{7} & 215 & $0 \cdot 2$ & 0.61 & ++ & 23 \\
\hline 228 & & 160 & 0.2 & $0.01 \mathrm{M}$ & + & 22 \\
\hline 188 & \multirow[t]{2}{*}{9} & 230 & 0.3 & $0 \cdot 61$ & ++ & 12 \\
\hline 221 & & 250 & 0.2 & $0.01 \mathrm{M}$ & ++ & 26 \\
\hline 293 & 10 & 245 & 0.2 & 0.61 & ++ & 6 \\
\hline 177 & 11 & 300 & 0.2 & 0.61 & ++ & 18 \\
\hline 302 & 12 & 230 & $0 \cdot 2$ & 0.61 & ++ & 20 \\
\hline 197 & \multirow[t]{4}{*}{14} & 230 & 0.2 & 0.61 & ++ & 5 \\
\hline 229 & & 235 & $0 \cdot 2$ & 0.61 & ++ & 24 \\
\hline 237 & & 300 & $0 \cdot 2$ & 0.61 & + & 24 \\
\hline 281 & & 260 & $0 \cdot 2$ & 0.61 & ++ & 7 \\
\hline 297 & 15 & 295 & $0 \cdot 2$ & 0.61 & ++ & 26 \\
\hline 230 & 18 & 270 & 0.2 & 0.61 & ++ & 18 \\
\hline 274 & \multirow[t]{2}{*}{19} & 370 & $0 \cdot 2$ & 0.61 & 0 & - \\
\hline 278 & & 420 & $\begin{array}{l}0 \cdot 18 \mathrm{R} \\
0 \cdot 2 \mathrm{~L}\end{array}$ & $\begin{array}{l}0.5 \\
0.5\end{array}$ & $\begin{array}{l}++ \\
+\end{array}$ & $\begin{array}{l}24 \\
\text { Not recorded }\end{array}$ \\
\hline 236 & 20 & 340 & 0.2 & 0.61 & + & 23 \\
\hline
\end{tabular}


contin.

\begin{tabular}{|c|c|c|c|c|c|c|}
\hline Exp. No. & $\begin{array}{c}\text { Age } \\
\text { (days) }\end{array}$ & $\begin{array}{l}\text { Weight } \\
\text { (g.) }\end{array}$ & $\begin{array}{l}\text { Dose } \\
(\mathrm{ml} .)\end{array}$ & $\begin{array}{l}\text { Concentration } \\
\text { (per cent.) }\end{array}$ & $\begin{array}{l}\text { Degree of } \\
\text { Closure }\end{array}$ & $\begin{array}{l}\text { Time at which } \\
\text { Maximum Closure } \\
\text { was Seen (min.) }\end{array}$ \\
\hline 231 & \multirow[t]{2}{*}{21} & 300 & $0 \cdot 2$ & 0.61 & ++ & 23 \\
\hline 284 & & 360 & $0 \cdot 2$ & 0.61 & + & 10 \\
\hline 279 & 22 & 390 & $0 \cdot 2$ & 0.61 & 0 & - \\
\hline 241 & 25 & 330 & $0 \cdot 2$ & 0.61 & ++ & 28 \\
\hline 270 & \multirow[t]{2}{*}{30} & 390 & $0 \cdot 2$ & 0.61 & ++ & 18 \\
\hline 245 & & \multirow[t]{2}{*}{440} & $0 \cdot 2$ & $0 \cdot 61$ & 0 & - \\
\hline 271 & 34 & & $\begin{array}{l}0 \cdot 2 \mathrm{R} \\
0 \cdot 2 \mathrm{~L}\end{array}$ & $\begin{array}{l}0.61 \\
0.61\end{array}$ & $\begin{array}{l}0 \\
++\end{array}$ & $\overline{28}$ \\
\hline 235 & 42 & 510 & $0 \cdot 2$ & $0 \cdot 61$ & + & 18 \\
\hline 250 & 50 & 700 & $\begin{array}{l}0 \cdot 2 \mathrm{R} \\
0 \cdot 2 \mathrm{~L}\end{array}$ & $\begin{array}{l}0.01 \mathrm{M} \\
0.61\end{array}$ & $\begin{array}{l}+ \\
+\end{array}$ & $\begin{array}{l}24 \\
20\end{array}$ \\
\hline 251 & 62 & 850 & $\begin{array}{l}0 \cdot 2 \mathrm{R} \\
0 \cdot 2 \mathrm{~L}\end{array}$ & $\begin{array}{l}0 \cdot 61 \\
0 \cdot 61\end{array}$ & $\begin{array}{l}0 \\
0\end{array}$ & - \\
\hline 291 & 73 & 1,050 & $0 \cdot 25$ & 0.61 & 0 & - \\
\hline 180 & \multirow[t]{5}{*}{ Adult } & - & $2 \cdot 6$ & 0.61 & 0 & - \\
\hline 198 & & 3,400 & $0 \cdot 2$ & 0.61 & 0 & - \\
\hline 204 & & 2,900 & 0.5 & 0.61 & 0 & - \\
\hline 226 & & 3,300 & 0.25 & $0 \cdot 61$ & 0 & - \\
\hline 249 & & 3,600 & $\begin{array}{l}0 \cdot 2 \mathrm{R} \\
0 \cdot 2 \mathrm{~L}\end{array}$ & $\begin{array}{l}0.61 \\
0.61\end{array}$ & $\begin{array}{l}0 \\
0\end{array}$ & - \\
\hline
\end{tabular}

\section{Results and Interpretation}

The Table shows the effect of intravitreally injected sodium fluoride on the retinal vessels of kittens of different ages, starting at 6 days and ending with the results of five experiments performed on fully adult animals. In all cases, unless otherwise stated, the injection consisted of $0.2 \mathrm{ml}$. of an $0 \cdot 61$ per cent. solution of Analar sodium fluoride. The sixth column from the left indicates whether the resultant vaso-obliteration was complete $(++)$, incomplete $(+)$, or absent $(0)$, and the right-hand column shows the time after injection at which maximum closure was seen. The degree of vasoobliteration produced in any single case was assessed only at the site of injection, the reason being that the extent of the closure depended in some measure upon the spread of the injected sodium fluoride within the subhyaloid space and the spread of the fluoride in turn depended upon the exact position of the needle tip and was thus subject to slight variations. Where complete 
vaso-obliteration is recorded, however, this indicates local obliteration of all vessels with the occasional exception of the main veins. Where incomplete closure is recorded this indicates that some part of the arterial circulation was not completely closed by the injection. The zero sign has only been used where the sodium fluoride failed to produce any significant vasoobliteration. The closure produced by sodium fluoride occurs in a specific sequence (Ashton and others, 1957), and can easily be distinguished from other changes in the calibre of the vessels. For example, in a few experiments on older animals (not included in the Table), some obliteration was noted within 2 or 3 minutes of injection. It could be seen that this took the form of a localized and uneven change in thickness of the vessel wall and was not due to changes in the surrounding retinal tissue. Furthermore, it was rapidly reversed by intravitreal injection of 1 per cent. Amethocaine. The true fluoride-induced closure was unaffected by this substance, and would in fact proceed to completion in its presence, suggesting that vascular spasm was involved as a separate entity in these experiments. Despite these factors, it still remains apparent that the reactivity of the retinal vessels to local sodium fluoride starts to become inconstant between the ages of 14 and 21 days and becomes gradually less with increasing age until after approximately 50 days the vessels are apparently unaffected. It has previously been reported (Ashton and others, 1954) that a raised ambient oxygen concentration will produce total or severe vaso-obliteration from 1 to 14 days of age, and mild vaso-obliteration from 15 to 21 days of age, and it is doubtful or absent after this period. Joint consideration of these two groups of experiments indicates that the developing retinal vessels gradually cease to react to both hyperoxia and sodium fluoride within age limits which are comparable if it is accepted that an intravitreal injection of an enzyme poison is probably a more potent procedure than raising the ambient oxygen concentration.

A correlation of this nature does not of course suggest that the mechanisms involved are identical, and considerable experimental work is still necessary before the degree of similarity between the vaso-obliterative properties of the two agents can be finally established.

\section{Summary}

(1) Experiments are described which show that the vaso-obliterative effect of sodium fluoride on the vessels of the immature retina starts to become inconstant between the ages of 14 and 21 days, and becomes gradually less in increasingly older animals, until after approximately 50 days the calibre of the vessels is no longer affected.

(2) This finding is related to the well-established correlation between age and the vaso-obliterative effect of ambient hyperoxia. 
It is a pleasure to record the encouragement and helpful criticism I have received from Prof. Norman Ashton during the performance of these experiments.

I should also like to thank Mr. G. Knight, Miss E. Robins, and Miss E. FitzGerald for their assistance. The Medical Research Council kindly made a grant towards the expenses entailed in this work.

\section{REFERENCES}

Ashron, N., and CooK, C. (1954). Brit.J. Ophthal., 38, 433.

, Graymore, C., and Pedler, C. (1957). Ibid., $41,449$.

WARD, B., and SERPELl, G. (1953). Ibid., 37, 513.

-

GRAYMORE, C. (1958). Ibid., 42, 348.

PEDler, C. (1957). Ibid., 41, 174.

(1959). Ibid., 43, 559 . 